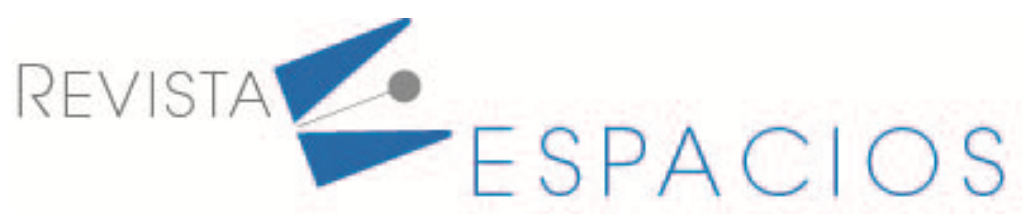

\title{
Agri-food market of Russia in the Food Security System
}

\author{
Mercado agroalimentario de Rusia en el Sistema de Seguridad Alimentaria
}

\author{
SHARAPOVA, Valentina M. ${ }^{1}$ \\ SHARAPOVA, Natalia V. ${ }^{2}$
}

\begin{abstract}
The relevance of the study lies in the fact that the problem of food security remains and has a planetary scale. Food production of appropriate quality and quantity, at a certain price level, is one of the country's development priorities. The purpose of the article is to analyze the influence of various factors on the food security of Russia. The problem of food security can only be solved by creating a set of conditions, such as: creating a mechanism for state regulation of the industry, increasing the level of population incomes, ensuring parity of prices between agricultural and manufactured industrial products (for agricultural purposes), limiting the volume of food imports, and ensuring the agricultural sector of the economy material and technical base.

key words: food security, food, population incomes, wholesale food markets.

Resumen

La relevancia del estudio radica en el hecho de que el problema de la seguridad alimentaria persiste y tiene una escala planetaria. La producción de alimentos de calidad y cantidad adecuadas, a un cierto nivel de precios, es una de las prioridades de desarrollo del país. El problema de la seguridad alimentaria solo puede resolverse mediante la creación de un conjunto de condiciones, tales como: crear un mecanismo para la regulación estatal de la industria, aumentar el nivel de ingresos de la población, garantizar la paridad de los precios entre los productos industriales agrícolas y manufacturados (para fines agrícolas), limitar el volumen de las importaciones de alimentos y garantizar el sector agrícola de la economía material y base técnica.

Palabras clave: seguridad alimentaria, alimentos, ingresos familiares, mercados mayoristas de alimentos
\end{abstract}

\section{Introduction}

Scientists from all countries consider the problem of food security in their research, it is one of the global, therefore it is planetary in nature. Every year, the number of inhabitants of the planet is undernourished and suffering from hunger. Particularly acute is the situation in South America and most regions of Africa.

The problem of food security cannot be solved only by the forces of farmers. A comprehensive approach is needed aimed at improving the quality of life of the population, the development and implementation of sociallyoriented policies, state and interregional regulation of agricultural production. At the end of 2018, the Russian Federation took 42nd place in the ranking of the Global Food Security Index, compiled by Corteva Agriscience and the analytical agency Economist Intelligence Unit (EIU). The top ten countries include: Singapore (Index 85.9),

\footnotetext{
${ }^{1}$ Doctor of Economics, Professor, Ural State University of Economics, e-mail: sharapova_vm@usue.ru

2 PhD in Economics, Associate Professor, Ural State University of Economics, e-mail: sharapov.66@mail.ru
} 
Ireland (Index 88.5), United Kingdom (Index 85.0), USA (Index 85.0), Netherlands (Index 84.7), Australia (Index $83,7)$, Switzerland (Index 83.5), Finland (Index 83.3), Canada (Index 83.2), France (Index 82.9).

\subsection{Basic provisions}

- the level of self-sufficiency in certain foods (milk and dairy products, vegetables, fruits, salt) remains low;

- the development of agriculture is facilitated by the regulation of effective demand;

- the complexity of agricultural production remains high, while wages are below the average Russian level;

- technologies and equipment in agricultural production have low efficiency, as a result of which the profitability of agricultural products is low.

\section{Metodology}

When conducting studies related to food security, methods of system analysis, monographic studies, a differentiated approach to assessing competitiveness, and graphical methods were used.

At the beginning of 2020, the Russian Federation did not reach the recommended level of consumption of such products as milk and dairy products, vegetables and fruits.

The share of agriculture of the Russian Federation in gross domestic product in 2018 compared to the 1990 level decreased 4.8 times; in investments in fixed assets by 3.6 times (Fig. 1).

Figure 1

The share of agriculture of the Russian Federation

in the economy of the national economy, $\%$

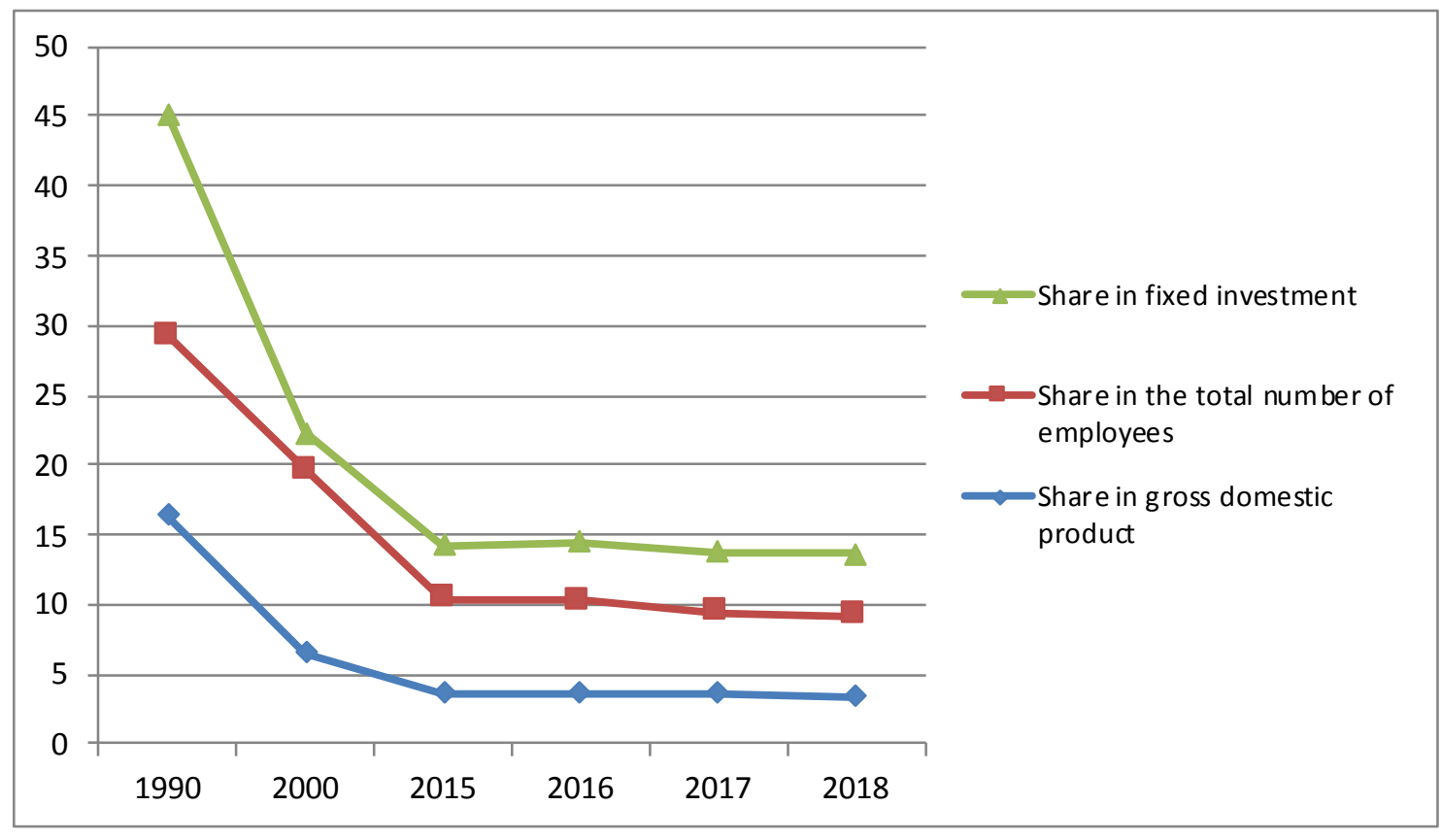

Fuente: https://www.gks.ru/

Until now, the remuneration of agricultural producers remains low [9]. In 2018, it amounted to $65.6 \%$ of the average Russian level (Tab. 1). 
Table 1

Overdue wage arrears of agricultural workers and the ratio of the average monthly wage of farmers with the average Russian level

\begin{tabular}{|l|c|c|c|c|c|}
\hline Indicator & 2000 & 2015 & 2016 & 2017 & 2018 \\
\hline $\begin{array}{l}\text { "The average monthly accrued } \\
\text { wages"[15], rub. }\end{array}$ & 985,0 & 19721,0 & 21755,0 & 25671,0 & 28699,0 \\
\hline $\begin{array}{l}\text { The ratio of wages of agricultural } \\
\text { enterprises to the average Russian } \\
\text { salary level,\% }\end{array}$ & 40,1 & 57,9 & 59,3 & 65,5 & 65,6 \\
\hline $\begin{array}{l}\text { "Amount of overdue wage arrears" } \\
{[15] \text { in agricultural organizations, }} \\
\text { million rubles }\end{array}$ & 7816 & 182 & 189 & 158 & 133 \\
\hline
\end{tabular}

Fuente: https://www.gks.ru/; https://gtmarket.ru/ratings/global-food-security-index/info

Despite the narrowing of the gap between the average monthly wage of agricultural workers and the average Russian level, the amount of overdue wage arrears to farmers remains quite high. [13]

As mentioned above, the level of consumption of staple foods remains below rationally established standards for such foods as milk and dairy products, salt.

Figure 2

Target indicators of the State program for the development of agriculture and regulation of agricultural products, raw materials and food markets for 2013-2020; thresholds established in the Russian Federation by the Food Security Doctrine in 2010 and 2020

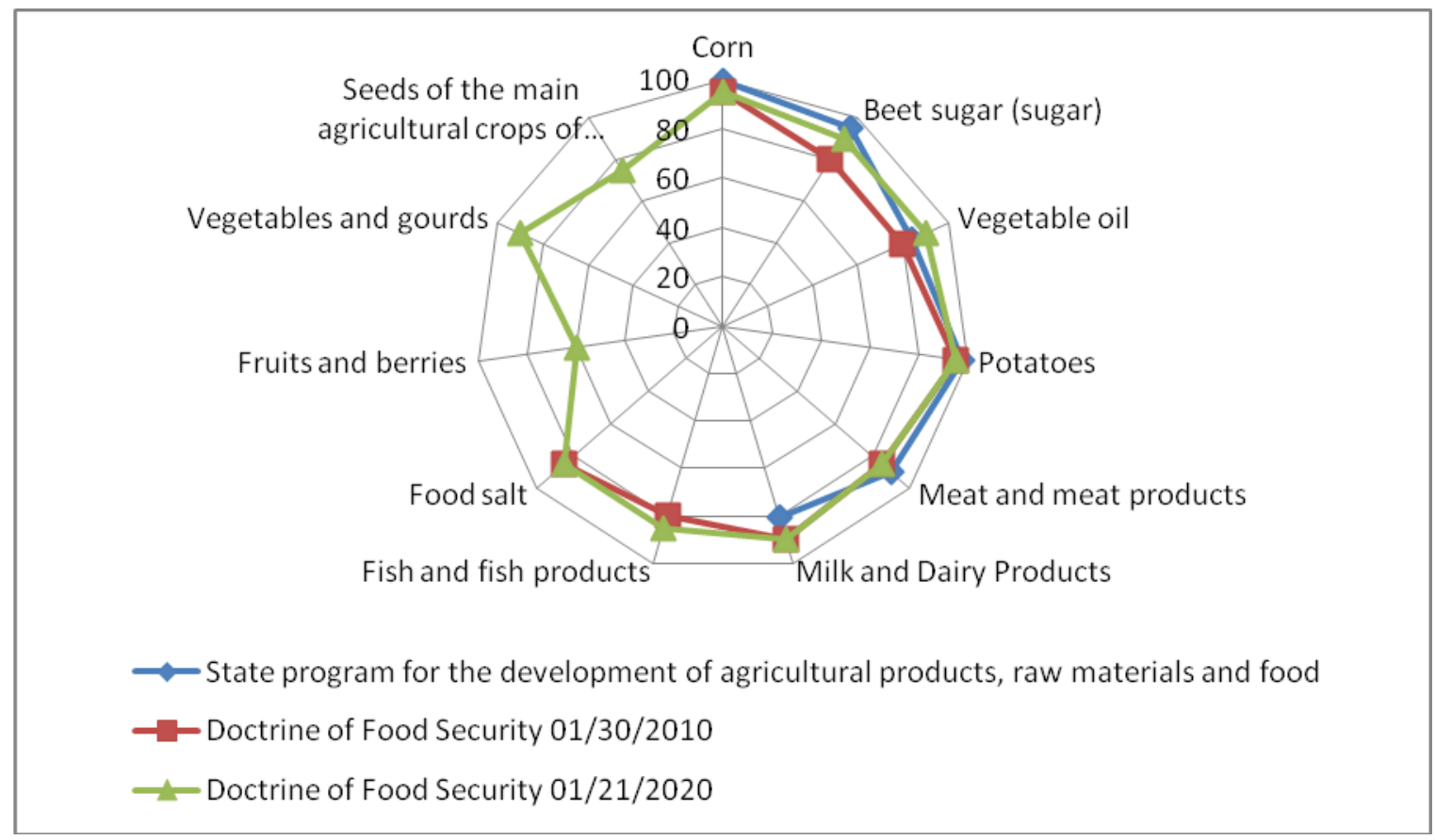

Fuente: https://produccioncientificaluz.org/index.php/opcion/article/view/23813.; https://www.gks.ru/

The graph in Figure 2 clearly demonstrates the established key indicators by the Food Security Doctrines in 2010 and 2020, and the State Program for the Development of Agriculture and the regulation of agricultural products, raw materials and food markets, and we can note their identity by the main indicators.

Let us consider in Figure 3 the level of consumption in the Russian Federation of basic foodstuffs per capita in 2000 - 2018. 
Figure 3

The level of consumption of basic food products per capita in the Russian Federation in 2000 - 2018.



The structure of consumption of basic foodstuffs differs with respect to rational norms of consumption (Figure 4).

Figure 4

Comparison of the rational consumption rate and actual per capita consumption in the Russian Federation for basic food products in 2018

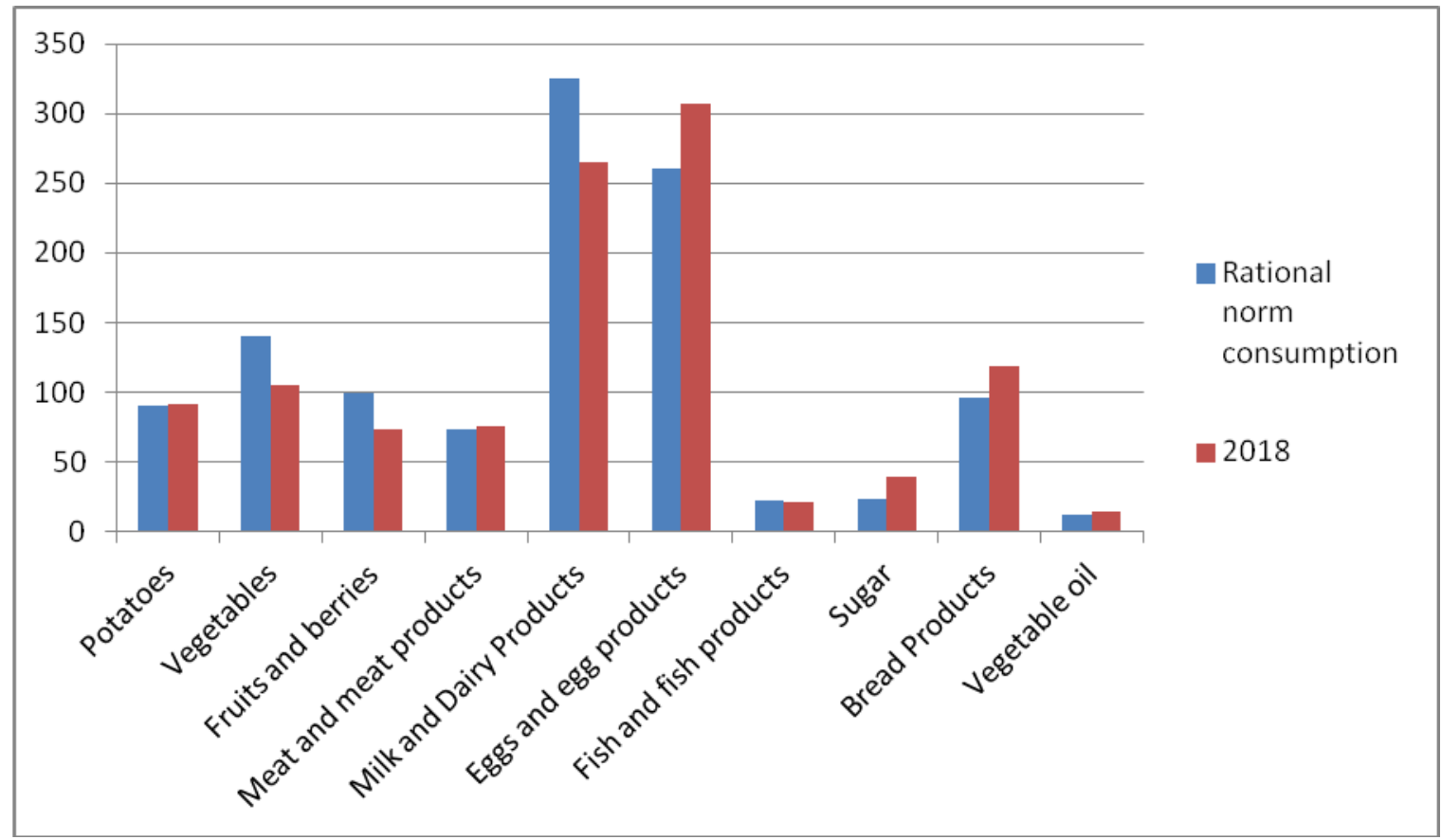

Fuente: https://www.gks.ru/ 
So, we note that in 2018 the level of self-sufficiency in basic foodstuffs in the Russian Federation was not reached: $[8,10]$ so, for milk and dairy products, the actual consumption rate is lower than rational by $18.7 \%$, fruits and berries are lower than rational consumption rate by $26,3 \%$, vegetables - by $24.6 \%$, fish and fish products - by $1.4 \%$; at the same time, meat and meat products $(+2.9 \%)$, for potatoes $(+1.1 \%)$, for eggs and egg products $(+$ $18.1 \%)$, for bread products $(+23.2 \%)$, for oil vegetable $(+15.8 \%)$, sugar $(+64.1 \%)$ above the rational consumption rate.

At the same time, the Russian Federation annually exports and imports both products of plant and animal origin (Tab. 2, 3).

Table 2

Import of animal and vegetable products

in the Russian Federation, 2017-2019

\begin{tabular}{|c|c|c|c|c|c|c|}
\hline \multirow{2}{*}{ Indicators } & \multicolumn{2}{|c|}{2017 г. } & \multicolumn{2}{|c|}{2018 г. } & \multicolumn{2}{c|}{2019 г. } \\
\cline { 2 - 6 } & $\begin{array}{c}\text { million } \\
\text { dollars }\end{array}$ & $\begin{array}{c}\text { thousand } \\
\text { tons }\end{array}$ & $\begin{array}{c}\text { million } \\
\text { dollars }\end{array}$ & $\begin{array}{c}\text { thousand } \\
\text { tons }\end{array}$ & $\begin{array}{c}\text { million } \\
\text { dollars }\end{array}$ & 2,81 \\
\hline $\begin{array}{c}\text { "Products of animal } \\
\text { origin" [15] }\end{array}$ & 7,27 & 2,81 & 6,24 & 2,35 & 1,01 \\
\hline $\begin{array}{c}\text { "Products of plant } \\
\text { origin" [15] }\end{array}$ & 10,8 & 12356 & 11,3 & 12451 & 5,15 & 5416 \\
\hline
\end{tabular}

Fuente: https://www.gks.ru/

For the period from 2017 to 2019. The main importers of animal products to the Russian Federation were: Belarus (39.2\%), Brazil (10.9\%), Chile (7.2\%), Argentina (5.6\%); of plant origin: Ecuador (10.9\%), China (9\%), Turkey (8.4\%), Brazil (6.5\%) and other countries. [14.16]

Table 3

Export of animal and vegetable products from the Russian Federation, 2017-2019

\begin{tabular}{|c|c|c|c|c|c|c|}
\hline \multirow{2}{*}{ Indicators } & \multicolumn{2}{|c|}{2017} & \multicolumn{2}{|c|}{2018} & \multicolumn{2}{c|}{2019} \\
\cline { 2 - 6 } & $\begin{array}{c}\text { million } \\
\text { dollars }\end{array}$ & $\begin{array}{c}\text { thousand } \\
\text { tons }\end{array}$ & $\begin{array}{c}\text { million } \\
\text { dollars }\end{array}$ & $\begin{array}{c}\text { thousand } \\
\text { tons }\end{array}$ & $\begin{array}{c}\text { million } \\
\text { dollars }\end{array}$ & 2,09 \\
\hline $\begin{array}{c}\text { "Products of animal } \\
\text { origin" [15] }\end{array}$ & 4,19 & 2137 & 5,09 & 2329 & 1037 \\
\hline $\begin{array}{c}\text { "Products of plant origin" } \\
\text { [15] }\end{array}$ & 9,15 & 47541 & 12,2 & 59767 & 3,54 & 14505 \\
\hline
\end{tabular}

Fuente: https://www.gks.ru/

From Russia, plant products are exported to the following countries: Egypt (15.5\%), Turkey (12.3\%), Iran (4.8\%), Bangladesh (3.7\%) and others. Animal products were exported to China (30.2\%), South Korea (27.6\%), the Netherlands (13.8\%), Japan (5.7\%), Kazakhstan (4\%) and other countries [11,12].

The dependence on imported products for such commodity resources as beef remains high $-40.7 \%$; table salt $35.4 \%$; milk powder (cream powder and dry mixes for ice cream) - 37.4\%; cheeses - $29 \%$ (Figure 5). 
Figure 5

The share of imports of individual consumer goods

in their commodity resources for 2016-2018.,\%



Fuente: https://www.gks.ru/

A significant proportion of beef is acquired by import, which does not allow full use of the reproductive capabilities of agricultural producers $[1,2,3]$. Beef production so far remains generally unprofitable, but agricultural organizations have emerged that have solved this problem through scientifically sound work organization, the procurement of domestic high-quality feed, and raising the wages of livestock breeders. This experience should gradually be extended to other organizations, which will increase the profitability of beef production and solve the problem of dependence on imports.

\section{Results}

At the same time, there is a positive trend, the competitiveness of domestic agricultural products is growing. However, the country cannot be completely import-independent, since there is no possibility to grow exotic types of fruits and vegetables, as well as to produce some types of products [6,7]. An analysis of the factors affecting the country's food security allows them to be structured into several groups: export-import supplies of raw materials and food, the creation of internal food reserves, the development of the national agro-industrial complex market, the validity of pricing for agricultural products, the validity of state policy in providing food to various groups of the population, international cooperation in the agricultural sector. When assessing the influence of factors, the lack of investment resources in the agricultural sector of the economy was revealed. Thus, these factors can have a different impact in the development of federal and regional programs in the field of food security.

Monopoly trading networks, which, when establishing significant trade margins, force agricultural producers to sell their products at low prices, also hinder the development of the agricultural sector of the economy.

Monopolistic trading networks, which, when establishing significant trade margins, force agricultural producers to sell their products at low prices, also hinder the development of the agricultural sector of the economy. 


\section{Conclusions}

The problem of food security must be addressed by eliminating the disparity in prices for agricultural and manufactured industrial products. And also due to regulation by the state of retail prices for food products, which negatively affects food security while reducing the purchasing power of the population. The establishment of purchasing cooperatives can also stabilize procurement prices, with the aim of creating competition for resellers of agricultural raw materials and food. A rational solution may be the revival of wholesale consumer markets.

\section{References}

Dvoryadkina, E.B., Belousova, E.A. (2018). Factors and trends in the development of local budgets of rural territories. Revista ESPACIOS. 39 (39). 13. Retrieved from:

https://www.semanticscholar.org/paper/Factors-and-trends-in-the-development-of-local-of-DvoryadkinaBelousova/d5504a8f83da18a3679a71c38e69346844c535c0.

Nabokov, V.I., Mingalev, V.D., Pustuyev, A.L., Sharapova, V.M., Grytsova, O.A., Rubayeva, O.D., Razorvin, I.V. (2018). Marketing information analysis on educational service quality in terms of innovative activity. The Turkish Online Journal of Design, Art and Communication TOJDAC, Special Edition, 31-38., Retrieved from: https://elibrary.ru/item.asp?id=36495694.

Rubaeva, O., Pogartseva, E., Kot, E., Nikitina, T. (2018). Resources provision of rural territories social sphere: A case study. Journal of Environmental Management and Tourism. 9.7 (31). 1512-1524. Retrieved from: https://www.semanticscholar.org/paper/Resources-Provision-of-Rural-Territories-Social-A-RubaevaPogartseva/fb7f3914cc8c3dd4b1012b3eba02a5c4ed95769d.

Semin, A.N., Kurdymov, A.V. (2018). International food security regulation assessment. Opcion. 34. (85). 628651. Retrieved from: https://produccioncientificaluz.org/index.php/opcion/article/view/23813.

Semin, A.N. , Sharapova, V.M., Sharapova, N.V. (2015). Agro-industrial complex of the middle Urals: functioning problems and development vector. European Applied Sciences: challenges and solutions 1st International Scientific Conference. Stuttgart. 170-173. Retrieved from: https://elibrary.ru/item.asp?id=24880778. (in Russ.).

Sharapova, V.M., Sharapova, N.V. (2016). International economic sanctions and their impact on the agricultural sector. Actual problems of the humanities and natural sciences. 1-5. 39-42. Retrieved from: https://elibrary.ru/item.asp?id=25503022. (in Russ.).

Sharapova, V.M., Sharapova, N.V., Semina, N.A. (2019). Employment of young specialists in rural territories. Revista ESPACIOS. 40 (42). 1. Retrieved from: https://www.semanticscholar.org/paper/Employment-ofyoung-specialists-in-rural-Sharapova Sharapova/dd49a510be6f4d05192c1749aa8b23903b9cb1ee.

Sharapova, N.V., Sharapova, V.M. (2018).Program-targeted management of the agricultural sector. Proceedings of the 32nd International Business Information Management Association Conference, IBIMA 2018 - Vision 2020: Sustainable Economic Development and Application of Innovation Management from Regional expansion to Global Growth 32.5455-5458. Retrieved from: https://ibima.org/accepted-paper/programtargeted-management-of-the-agricultural-sector/.

Sharapova, N., Sharapova, V. (2019). State regulation of wages in the agro-industrial complex of Russia. Proceedings of the 33rd International Business Information Management Association Conference, IBIMA 2019: Education Excellence and Innovation Management through. 4734-4738. Retrieved from: https://ibima.org/accepted-paper/state-regulation-of-wages-in-the-agro-industrial-complex-of-russia/. 
Shelkovnikov, S.A., Matvienko, S.N., Vyshegurov, M.S., (...), Semina, L.A., Petukhova, N.V. (2017). Boosting the efficiency of agricultural organizations taking into account the state support (a case study of the Novosibirsk region). International Journal of Economic Research. 14. 16. 419-435. Retrieved from: https://elibrary.ru/item.asp?id=35501215.

Vinnichek, L., Pogorelova, E., Dergunov, A. (2019) Oilseed market: Global trends. IOP Conference Series: Earth and Environmental Science.012030. Retrieved from: https://www.semanticscholar.org/author/L.-B.Vinnichek/114943751.

12. Voronin, B. A., Chupina, I. P., Sharapova, V.M., Maslakov, V. V., Fedorov, M. V., Cot, E. M., Mokronosov, A. G. (2017). Theoretical aspects of national food security provision issue. Turkish online journal of design art and communication volume. 2102-2108. Retrieved from: http://www.tojdac.org/tojdac/VOLUME7DCMSPCL_files/tojdac_v070DSE196.pdf

Voronin, B., Potekhin, N., Chupina, I., Sharapova, V., Kot, E., Razorvin, I.V., Mokronosov, A., Lysenko, J. (2018) Consequences of economic sanctions for food security of Russia. Journal of Environmental Management and Tourism. 8 (32).1799-1804. Retrieved from:

https://journals.aserspublishing.eu/jemt/article/view/3139

The share of imports of individual goods in their commodity resources Retrieved from: https://www.fedstat.ru/indicator/37191

Federal State Statistics Service. Retrieved from: https://www.gks.ru/

World Food Security Rankings Retrieved from: https://gtmarket.ru/ratings/global-food-security-index/info

Esta obra está bajo una Licencia Creative Commons Attribución-NoCommercial 4.0 International

(cc) BY-NC 